\title{
Ice nucleation activity in Pantoea ananatis obtained from maize white spot lesions
}

\author{
Atividade de nucleação de gelo em Pantoea ananatis \\ obtidos de lesões da mancha branca do milho
}

\author{
Aline Vanessa Sauer ${ }^{*}$; Kátia Real Rocha²; Eliseu dos Santos Pedro²; \\ Walter Fernandes Meirelles ${ }^{3}$; Luzia Doretto Paccola-Meirelles ${ }^{4}$
}

\begin{abstract}
Maize white spot lesions caused by Pantoea ananatis has contributed substantially to yield reduction of maize crops in many countries, including Brazil. The initial symptoms of the disease include watersoaked lesions on the leaves, which later become necrotic and straw-colored. Basic knowledge regarding the biology and the infection mechanisms of this pathogen is lacking. In this study, 15 P. ananatis isolates obtained from maize white spot lesions were examined for their ice nucleation activity (INA). The INAs of individual bacterial isolates was determined by tube nucleation tests. Bacterial isolates were grown on tryptic soy broth medium and an aliquot of $0.1 \mathrm{~mL}$ of culture was added to test tubes containing $1 \mathrm{~mL}$ of sterile distilled water. The tubes were packed in an ice bath, which had a temperature below $-10^{\circ} \mathrm{C}$, for approximately $2 \mathrm{~min}$. Instantaneous formation of ice in the tube revealed a positive INA phenotype of the isolate. Only 9 of the 15 studied isolates showed the INA ${ }^{+}$phenotype. Pathogenicity tests were performed using whole plants and detached leaves. Symptoms were reproduced in both tests, but only for the inoculations using INA ${ }^{+}$isolates. Electron microscopy allowed visualization of protein vesicles under outer cell wall of isolates characterized as INA ${ }^{+}$.
\end{abstract}

Key words: INA, vesicle protein, transmission electron microscopy

\section{Resumo}

Lesões de mancha branca do milho causadas por Pantoea ananatis contribuiram substancialmente para a redução da produtividade nos cultivos de milho, em muitos países, incluindo o Brasil. Os sintomas iniciais da doença incluem lesões anasarcas nas folhas, que mais tarde tornam-se necróticas e de cor palha. O conhecimento básico sobre a biologia e os mecanismos de infecção deste patógeno são escassos. Neste estudo, 15 isolados de $P$. ananatis obtidos a partir de lesões da mancha branca do milho foram examinados quanto à sua atividade de nucleação de gelo (INA). A INA de isolados bacterianos individuais foi determinada por testes de nucleação em tubos. Isolados bacterianos foram cultivados em meio de caldo de soja tríptico e uma alíquota de $0,1 \mathrm{~mL}$ de cultura foi adicionada à tubos de ensaio contendo $1 \mathrm{~mL}$ de água destilada esterelizada. Os tubos foram colados em banho de gelo, o qual continha temperatura inferior a $-10{ }^{\circ} \mathrm{C}$, por aproximadamente $2 \mathrm{~min}$. A formação de gelo instantânea no tubo revelou um fenótipo INA positivo do isolado. Apenas 9 dos 15 isolados estudados apresentaram o fenótipo INA+. Testes de patogenicidade foram realizados com plantas inteiras e folhas destacadas.

\footnotetext{
${ }^{1}$ Eng $^{\mathrm{a}} \mathrm{Agr}^{\mathrm{a}}$, Discente de Mestrado em Agronomia, Centro de Ciências Agrárias, Programa de Pós Graduação em Agronomia, Universidade Estadual de Londrina, UEL, Londrina, PR, Brasil. Bolsista CNPq. E-mail: aline.sauer@unopar.br

2 Discentes de Graduação, UEL, Londrina, PR, Brasil. Bolsista CNPq. E-mail: katiareal@msn.com; eliseu_pedro@cargill.com

${ }^{3}$ Eng $^{\circ}$ Agr $^{\circ}$, Dr. Pesquisador, Empresa Brasileira de Pesquisa Agropecuária, Embrapa Milho e Sorgo, Sete Lagoas, MG, Brasil. E-mail: walter.meirelles@embrapa.br

${ }^{4}$ Bióloga, Prof ${ }^{a}$ Dr $^{\mathrm{a}}$ Pesquisadora Senior, Dept ${ }^{\mathrm{o}}$ de Biologia Geral, CCB, UEL, Londrina, PR, Brasil. E-mail: paccola@uel.br

* Author for correspondence
} 
Os sintomas foram reproduzidos em ambos os testes, mas apenas para inoculações utilizando isolados INA+. A microscopia eletrônica permitiu a visualização de vesículas de proteínas sobre a parede celular externa de isolados caracterizados como INA+.

Palavras-chave: INA, vesícula proteica, microscopia eletrônica de transmissão

\section{Introduction}

Among the diseases that occur in maize culture in Brazil, maize white spot (MWS) has emerged as one of the most important because of its high incidence and severity in the field. This disease is found in nearly all maize-producing regions of the country (FERNANDES; OLIVEIRA, 2000). A reduction in the rate of photosynthesis occurs not only in injured tissue, but also in parts of remaining green tissues of infected leaves (GODOY; AMORIM; BERGAMIN FILHO, 2001). MWS symptoms typically appear in the lower leaves, and the early stage is characterized by small dark green water-soaked leaf spots that may be circular, oval, elliptical, or be slightly elongated to an oblong shape, 0.3 to 2.0 $\mathrm{cm}$ in diameter. Lesions are scattered over the leaf surface and have a chlorotic appearance, which later turn into pale green, dried straw-colored and necrotic (PACCOLA-MEIRELLES et al., 2001). Symptoms rapidly progress to the top of the plant, and the severity of MWS increases after tasseling (FERNANDES; OLIVEIRA, 2000).

A Gram-negative, facultative anaerobic, bright yellow, mucoid colony-forming, non-sporulating bacterium identified as Pantoea ananatis was described by Paccola-Meirelles et al. (2001) as the causal agent of MWS. This bacterium can survive epiphytically on maize leaves and trigger the disease in its host through a mechanism that remains unclear. According to Pomini, Paccola-Meirelles, and Marsaioli (2007), the quorum-sensing system is used to assess the population size by secreting substances such as acyl homoserine lactones (RUMJANEK; FONSECA; XAVIER, 2004). This mechanism may be associated with $P$. ananatis pathogenicity (MOROHOSHI et al., 2007), but the role of these signaling molecules in the pathogen is unknown.
Some species of bacteria can act as ice nucleating agents (INA bacteria), catalyzing icecrystal formation in supercooled fluids at relatively warm temperatures (MAKI et al., 1974). In the 1970s, it was found that some bacteria commonly associated with plants were capable of acting as ice nucleating agents at temperatures slightly below $0^{\circ} \mathrm{C}$ (LINDOW; ARNY; UPPER, 1978; LINDOW; ANDERSEN, 1996); these bacteria cause serious damage to their host due to supercooling at relatively high temperatures. Many plants, particularly those with their origin in tropical and/or subtropical regions, are unable to tolerate the ice formation in the intercellular spaces of their tissues. When this occurs, the membrane system of the plant cell collapses and a water-soaked spot appears, followed by tissue death by freezing (ROMEIRO, 2001). The damage to plants is due to ice formation in the intercellular spaces at temperatures where this phenomenon would not normally occur (LINDOW, 1983, 1987).

The aim of this study was to characterize $P$. ananatis isolates obtained from maize white spot lesions for their ice nucleating activity and evaluate the pathogenicity of these isolates on maize leaves.

\section{Materials and Methods}

Pantoea ananatis isolation from water-soaked lesions of maize white spot

The bacterial isolates used in this study were obtained from maize white spot lesions according to the method described by Paccola-Meirelles et al. (2001). 


\section{Ice nucleation activity assay}

Bacterial isolates were cultured in tryptic soy broth (TSB) medium for 24 hours under agitation $(60 \mathrm{rpm})$ at $30^{\circ} \mathrm{C}$. The culture was then homogenized using a vortex and a $0.1-\mathrm{mL}$ aliquot was added to test tubes containing $1 \mathrm{~mL}$ of sterile ultrapure water and kept in an ice bath at $-10^{\circ} \mathrm{C}$. Instantaneous formation of ice in the tube after addition of the bacterial suspension revealed the $\mathrm{INA}^{+}$phenotype. TSB medium without bacteria was used as a control.

\section{Transmission electron microscopy}

Two isolates of P. ananatis, WT2 and WT11, were cultured under agitation (60 rpm) in nutrient broth (NB) medium and NB medium plus 2.5\% glycerol (v/v) for 12 hours at $30^{\circ} \mathrm{C}$. Bacterial cells were separated from the medium by centrifugation at $15,700 \times g$ for $15 \mathrm{~min}$. The cells were fixed in a solution containing $3 \%$ glutaraldehyde in 0.1 $\mathrm{M}$ sodium cacodylate buffer $(\mathrm{pH}$ 7.2) at room temperature for 12 hours. Cells were washed in $0.1 \mathrm{M}$ sodium cacodylate buffer, post-fixed in $1 \%$ osmium tetroxide for 2 hours at room temperature, and washed again in the same buffer. The samples were dehydrated using increasing ethanol concentrations, soaked, and embedded in Araldite ${ }^{\circledR}$ resin (Electron Microscopy Sciences, Fort Washington, PA). Ultrathin cuts $(70 \mathrm{~nm})$ were made using a ultramicrotome (Ultracut; Leica, Solms, Germany) with a diamond knife ( $2 \mathrm{~mm}$ and $45^{\circ}$, DiATOME, Hatfield, PA, USA). The sections were deposited in 200 mesh screens and stained in uranyl acetate $(2 \%)$ and lead citrate (Reynolds solution). The screens were analyzed and photographed using a transmission electron microscope (TEM; FEI Tecnai 12, FEI, Hillsboro, OR, USA) in the Laboratory of Electron Microscopy and Microanalysis at the State University of Londrina.

\section{Pathogenicity tests}

\section{Pathogenicity test in greenhouse}

Pathogenicity tests using the $\mathrm{INA}^{+}$isolates (WT2, WT7, and WT11) and the INA- isolate (WT8) were carried out in susceptible cultivar DAS657 at 35 days old in a greenhouse. Three pots with three plants each were used. A pre-inoculum was prepared by cultivating each isolate in TSB medium for 12 hours at $30^{\circ} \mathrm{C}$ under agitation $(60 \mathrm{rpm})$. Next, the inoculum was prepared by transferring $1.0 \mathrm{~mL}$ of pre-inoculum to $100 \mathrm{~mL}$ TSB medium, followed by incubation of the sample under the same conditions for 4 hours. Saline solution $(\mathrm{NaCl} 0.85 \%)$ was added at a 1:1 (v/v) ratio to the bacterial culture. The culture remained at $4^{\circ} \mathrm{C}$ for 2 hours before being sprayed onto the maize leaves. The leaves were slightly injured with a sponge and immediately sprayed with the bacterial suspension. The plants were kept in a humidity chamber for 72 hours. As a control, the plants were sprayed only with TSB culture medium diluted in saline solution $(1: 1)$.

\section{Pathogenicity tests using detached leaves}

Pathogenicity tests in the laboratory were performed using detached leaves collected from 35day old plants of the susceptible cultivar DAS657, using the INA ${ }^{+}$isolates (WT2, WT7, WT11), and using INA-isolates (WT8, WT14). The leaves were detached, washed, and injured using a sponge. The leaves were clamped in 12-well microhumidity chambers that were $0.3 \mathrm{~cm}$ in diameter as described by Bergstrom and Nicholson (1983). For leaf inoculations $50-\mu \mathrm{L}$ drops of bacterial suspension were placed in individual wells. The bacterial inoculum and the control were prepared as previously described (4a item). The chamber wells were covered with adhesive tape, which remained for 72 hours. The experimental design was completely randomized with three replicates. 


\section{Results}

Variability in the ice nucleation ability of $P$. ananatis isolates obtained from water-soaked lesions of MSW was observed. Among the 15 randomly selected isolates, only 9 showed the $\mathrm{INA}^{+}$phenotype (Table 1). Additionally, there was variability in the bacterial population density required for occurrence of ice nucleation at the tested temperature. The isolates $\mathrm{INA}^{+}$, WT2, and WT11 were subjected to TEM. We observed vesicles at the cell walls of both isolates (Figure 1). Vesicles were similar to those described by Phelps et al. (1986), Michigami et al. (1995), and Kawahara (2002) in other bacterial species as being responsible for the formation of ice nuclei. The vesicles appeared in greater numbers when the bacterium was cultured in medium supplemented with glycerol (Figure 1B and $\mathrm{C}$ ).

Table 1. Ice nucleation activity and origin of the Pantoea ananatis isolates.

\begin{tabular}{lllc}
\hline \multicolumn{1}{c}{ Isolate } & \multicolumn{1}{c}{ Origin of material } & UFC/mL & INA \\
\hline EMS05 & Sete Lagoas - MG & $533 \times 10^{7}$ & + \\
WT2 & Warta - Londrina - PR & $275 \times 10^{7}$ & + \\
WT7 & Warta - Londrina - PR & $767 \times 10^{5}$ & - \\
WT8 & Warta - Londrina - PR & $326 \times 10^{7}$ & - \\
WT9 & Warta - Londrina - PR & $408 \times 10^{7}$ & + \\
WT11 & Warta - Londrina - PR & $119 \times 10^{9}$ & - \\
WT14 & Warta - Londrina - PR & $634 \times 10^{10}$ & + \\
F 102-1 & Embrapa Soja - Londrina - PR & $792.5 \times 10^{6}$ & - \\
F 102-2 & Embrapa Soja - Londrina - PR & $128.4 \times 10^{6}$ & + \\
F 102-4 & Embrapa Soja - Londrina - PR & $292.7 \times 10^{7}$ & - \\
F 103-1 & Embrapa Soja - Londrina - PR & $425 \times 10^{6}$ & + \\
F 103-2 & Embrapa Soja - Londrina - PR & $121 \times 10^{7}$ & + \\
F 103-3 & Embrapa Soja - Londrina - PR & $642.5 \times 10^{6}$ & + \\
F 103-5 & Embrapa Soja - Londrina - PR & $193.5 \times 10^{7}$ & - \\
F 103-8 & Embrapa Soja - Londrina - PR & $429 \times 10^{6}$ & - \\
\hline
\end{tabular}

* Concentration of bacterial suspension at time of testing.

Source: Elaboration of the authors.

The INA ${ }^{+}$isolates, WT2, WT7, and WT11, as well as the INA- isolate WT8, were subjected to a pathogenicity test in the greenhouse. The WT2, WT7, and WT11 isolates caused symptoms between the 7th and 9th days after inoculation, whereas the INA- isolate, WT8, developed no MWS symptoms. Control plants showed no symptoms (Figure 2).

Among the $\mathrm{INA}^{+}$isolates, WT7 caused a greater number of lesions when inoculated under greenhouse conditions (Table 2, Figure 2).
The INA ${ }^{+}$isolates WT2 and WT7, which were inoculated onto detached leaves in the microhumidity chambers, showed disease symptoms, but the results were similar to those observed for inoculation in the greenhouse. Symptoms were more pronounced for the WT7 isolate, which caused the highest average number of lesions (Table 2). The INA- isolates WT8 and WT14 developed no MWS symptoms in the pathogenicity test. Control leaves showed no symptoms (Figure 3). 
Figure 1. Transmission electron micrographs of Pantoea ananatis cells isolated from water-soaked spots lesions of MWS showing the presence of vesicles responsible for the release of ice nuclei (arrows). (A) WT2 isolate grown in NB medium, showing the formation of a single vesicle in the apical region of the cell. (B) and (C) WT2 isolate grown in NB + glycerol medium; note the increase in the number of vesicles (arrows) compared to the same isolate when grown in NB medium (A). (D) and (E) WT11 isolate grown in NB medium showing the presence of only one vesicle. (F) and (G) WT11 grown in $\mathrm{NB}+$ glycerol medium; note the increase in the number of vesicles (arrows) compared to the same isolate when grown in NB medium (D and E). Bacteria cultured in both culture media (NB and NB + glycerol) showed cellular vesicles with the same ultrastructural features. (A), (B), (C), (D), and (G), magnification, $97 \times$; scale bar, $200 \mathrm{~nm}$. (E) and (F), magnification, 235 $\times$ and scale bar, $100 \mathrm{~nm}$.
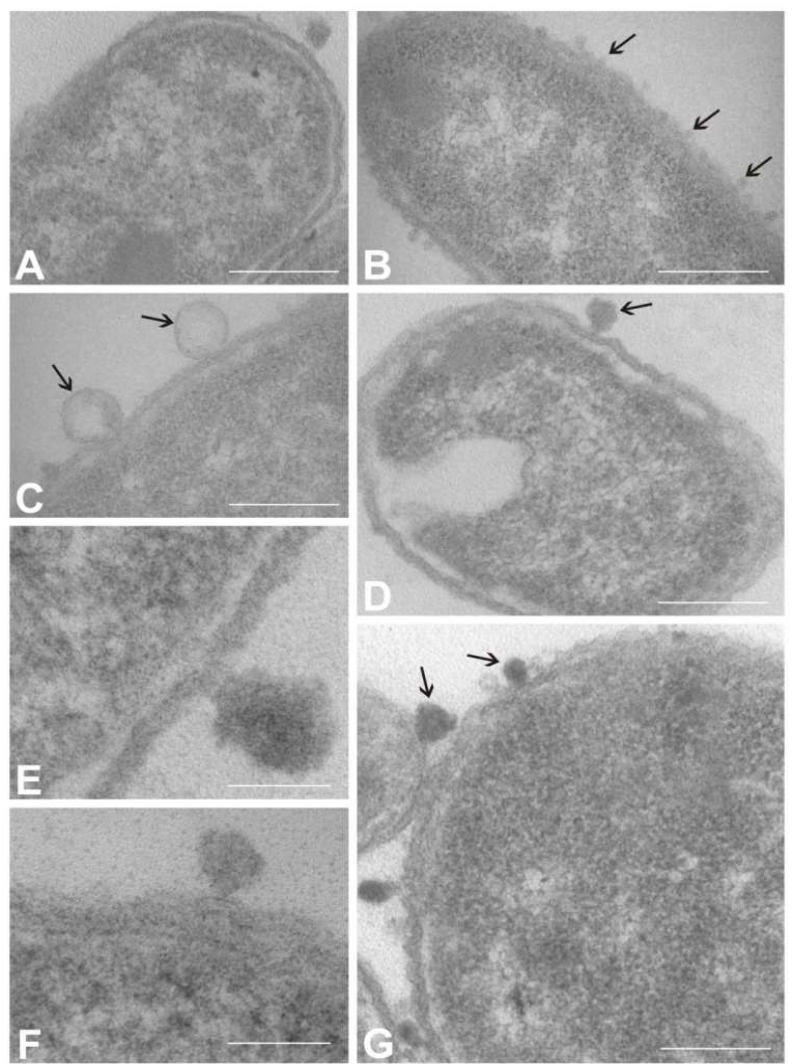

Source: Elaboration of the authors.
Figure 2. Pathogenicity test performed in maize plants (35 days old) under greenhouse conditions. (A) Control. (B) WT2 isolate. (C) and (D) WT7 isolate. (E) WT11 isolate.

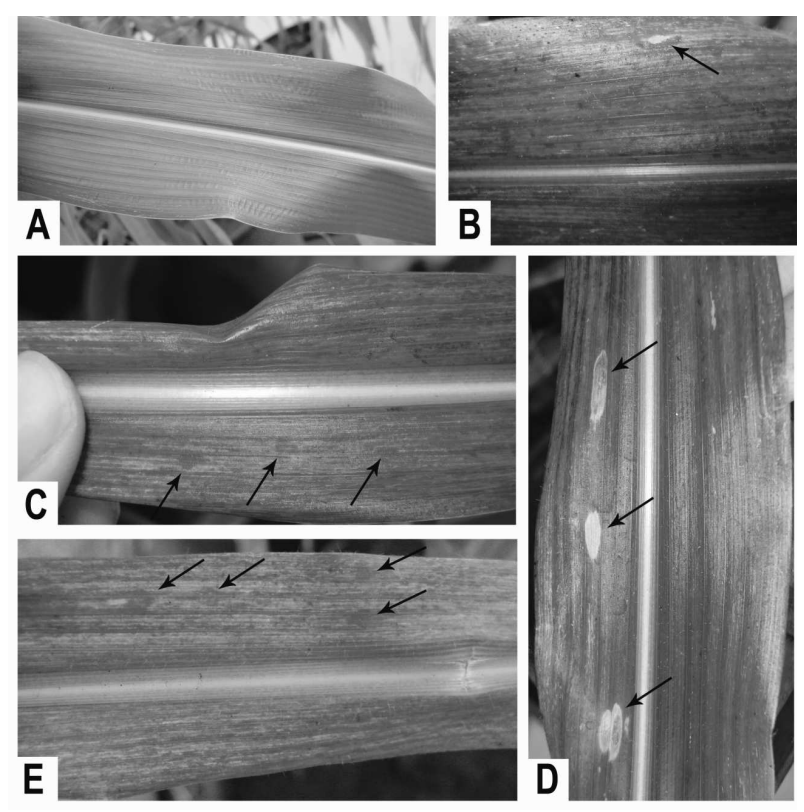

Source: Elaboration of the authors.

Figure 3. Pathogenicity test performed on maize detached leaves. (A) Control. (B) WT2 isolate. (C) WT7 isolate. (D) and (E) WT11 isolate. Lesions (arrows).
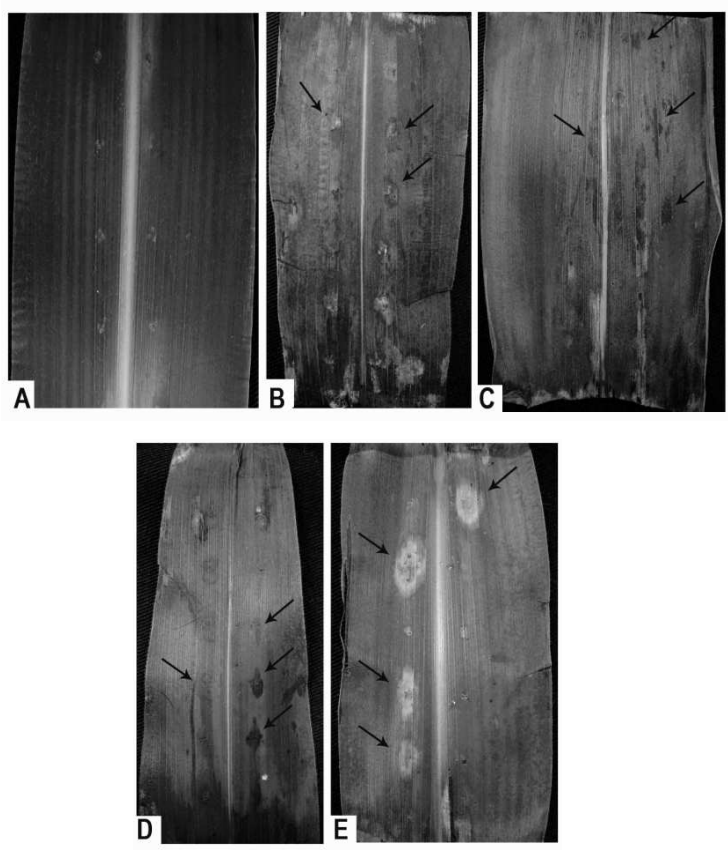

Source: Elaboration of the authors. 
Table 2. Number of lesions observed in the pathogenicity test when Pantoea ananatis isolates were inoculated in the greenhouse and in micro-humidity chambers onto maize leaves of cultivar DAS 657.

\begin{tabular}{lcc}
\hline \multirow{2}{*}{ Isolates } & \multicolumn{2}{c}{ Average numbers of lesions * } \\
\cline { 2 - 3 } & Greenhouse & Micro-humidity Chambers \\
\hline WT2 & $2.60 \mathrm{ab}$ & $3.00 \mathrm{~b}$ \\
WT7 & $4.40 \mathrm{a}$ & $8.67 \mathrm{a}$ \\
WT11 & $3.70 \mathrm{ab}$ & $4.33 \mathrm{~b}$ \\
WT8 & $0 \mathrm{c}$ & $0 \mathrm{c}$ \\
WT14 & - & $0 \mathrm{c}$ \\
Control & $0 \mathrm{c}$ & $0 \mathrm{c}$ \\
\hline
\end{tabular}

* Means followed by the same lowercase letter in the same column did not differ significantly according to Tukey's test. Source: Elaboration of the authors.

\section{Discussion}

Within most frost-sensitive plant tissues, water can be supercooled to between $-4^{\circ} \mathrm{C}$ and $-12^{\circ} \mathrm{C}$ without intracellular or extracellular freezing (SAKAI; LARCHER, 1987). However, when epiphytic populations of INA ${ }^{+}$bacteria are present, the bacteria can catalyze the freezing process at temperatures up to $-1.2^{\circ} \mathrm{C}$ (LINDOW, 1987).

Our results showed that some $P$. ananatis isolates from MWS lesions could catalyze ice formation in supercooled water, but not all isolates studied were ice-nucleation active at the temperature tested. Wysmierski, Escanferla and Paccola-Meirelles (2005) examined $P$. ananatis isolates from MWS lesions and observed variations regarding ice nucleation activity. According to Edwards et al. (1994), one of the most interesting aspects of bacterial INA is the unusual distribution of the phenotype. INA is found in species of the three genera Erwinia, Pseudomonas, and Xanthomonas; however, not all species within these genera exhibit the INA ${ }^{+}$phenotype. INA appears to be restricted to only Erwinia ananas, Erwinia uredovora, Erwinia herbicola, Pseudomonas syringae, Pseudomonas jluorescens, and Xanthomonas campestris (LINDOW, 1983). Further, not all strains within these six species share the $\mathrm{INA}^{+}$phenotype (LINDOW, 1983). The phenotypic distribution of the INA bacteria suggests that horizontal transfer occurred in the evolution of bacterial ina genes
(EDWARDS et al., 1994) or that the ina gene was present in a common ancestor of the $\mathrm{INA}^{+}$species and was subsequently lost from some strains. Thus, the species showed a dimorphic condition with regard to the presence or absence of the ina gene.

According to Lindow et al. (1982), not all cells of an INA isolate can undergo ice nucleation at any time and temperature, so the frequency of ice nucleation varies with the conditions under which the cells are grown, including temperature of incubation, composition of the culture medium, age of the culture, and the bacterium genotype. Nejad, Granhall and Ramstedt (2005), in agreement with Hirano, Baker and Upper (1985), observed that there is a relationship between the number of bacterial cells and ice nucleation activity, i.e. a certain population density is required for INA to function.

Electron micrographs showed that small vesicles, 50 to $200 \mathrm{~nm}$ in diameter, were present on the bacterial outer membrane and were shed into the growth medium. The largest number of vesicles was observed when bacteria were grown in medium supplemented with glycerol, in agreement with the results of Lindow et al. (1982). They observed that more ice nucleation was produced when glycerol was added to the culture medium. Vesicles showed no structural differences when cells were grown in NB or NB plus glycerol medium; there was only an increase in vesicle number. 
According to Lindow (1983), Phelps et al. (1986), and Kawahara (2002), protein molecules and materials located on the outer wall of some bacterial species are responsible for the ice nucleation mechanism. Few studies have been conducted to examine the structure and function of these proteins; additionally, the significance of the correlation between virulence and the $\mathrm{INA}^{+}$ phenotype has not been elucidated.

In the pathogenicity test, the reproduction of symptoms by $\mathrm{INA}^{+}$isolates was observed. The P. ananatis INA- isolates did not develop MWS symptoms in pathogenicity tests performed both in greenhouse and detached leaves. Lindow, Arny and Upper (1982), demonstrated a close link between ice nucleation activity and pathogenicity. Ice nucleation may also be an important factor in the virulence of pathogenic bacteria (EDWARDS et al., 1994), and according to Hirano and Upper (2000), the formation of leaf lesions can result from $\mathrm{INA}^{+}$bacterial overpopulation, which is associated with environmental factors such as humidity and temperature differences.

\section{Conclusions}

Pantoea ananatis isolates from MWS lesions can catalyze ice formation, but variability exists among isolates. Not all isolates exhibited the $\mathrm{INA}^{+}$ phenotype at the temperature examined.

Our results revealed the presence of vesicles on the cell surface of $\mathrm{INA}^{+}$isolates of $P$. ananatis obtained from MWS lesions, which is similar to the results of other authors who demonstrated the importance of vesicle presence in ice nucleation activity.

These isolates were able to infect plants not only in the greenhouse but also in detached leaves placed in micro humidity chambers under controlled conditions, indicating that a relationship exists between ice nucleation activity and the pathogenicity of $P$. ananatis in maize leaves.

\section{Acknowledgements}

The authors thank Professor Celia Guadalupe Tardeli de Jesus Andrade, Vanessa Veronese Ortunho, and Juca San Martin of the Laboratory of Electron Microscopy and Microanalysis of Universidade Estadual de Londrina for their contribution to the transmission electron microscopy analysis. The authors also thank Conselho Nacional de Desenvolvimento Científico e Tecnológico (CNPq) for financial support.

\section{References}

BERGSTROM, G. C.; NICHOLSON, R. L. Microhumidity chamber for quantitative inoculation of attached corn leaves with fungal pathogens. Phytopathology, Saint Paul, v. 73, n. 7, p. 1040-1042, 1983.

EDWARDS, A. R.; VAN DEN BUSSCHET, R. A.; WICHMAN, H. A.; ORSER, C. S. Unusual pattern of bacterial ice nucleation gene evolution. Molecular Biology and Evolution, Chicago, v. 11, n. 6, p. 911-920, 1994.

FERNANDES, F. T.; OLIVEIRA, E. Principais doenças na cultura do milho. $2^{\text {nd }}$ ed. Sete Lagoas: Embrapa Milho e Sorgo, 2000. $80 \mathrm{p}$.

GODOY, C. V.; AMORIM, L.; BERGAMIN FILHO, A. Alterações na fotossíntese e na transpiração de folhas de milho infetadas por Phaeosphaeria maydis. Fitopatologia Brasileira, Brasília, v. 26, n. 2, p. 209-215, 2001.

HIRANO, S. S.; UPPER, C. D. Bacteria in the leaf ecosystem with emphasis on Pseudomonas syringae - a pathogen, ice nucleus, and epiphyte. Microbiology and Molecular Biology Reviews, Washington, v. 64, n. 3, p. 624-653, 2000.

HIRANO, S. S.; BAKER, L. S.; UPPER, C. D. Ice nucleation temperature of individual leaves in relation to population sizes of ice nucleation active bacteria and frost injury. Plant Physiology, Lancaster, v. 77, n. 2, p. 259-265, 1985.

KAWAHARA, H. The structures and functions of ice crystal-controlling proteins from bacteria. Journal of Bioscience and Bioengineering, Osaka, v. 94, n. 6, p. 492-496, 2002.

LINDOW, S. E. Competitive exclusion of epiphytic bacteria by ice-Pseudomonas syringae mutants. Applied and Environmental Microbiology, Washington, v. 53, n. 10, p. 2520-2527, 1987. 
. The role of bacterial ice nucleation in frost injury to plants. Annual Review of Phytopathology, Palo Alto, v. 21, n. 1, p. 363-384, 1983.

LINDOW, S. E.; ANDERSEN, G. L. Influence of immigration on epiphytic bacterial populations on navel orange leaves. Applied and Environmental Microbiology, Washington, v. 62, n. 8, p. 2978-2987, 1996.

LINDOW, S. E.; ARNY, D. C.; UPPER, C. D. Erwinia herbicola ice nucleus active in increasing frost injury to corn. Phytopathology, Saint Paul, v. 68, n. 1, p. 523-527, 1978.

Bacterial ice nucleation: a factor in frost injury to plants. Plant Physiology, Washington, v. 70, n. 1, p. 1084-1089, 1982.

LINDOW, S. E.; HIRANO, S. S.; BARCHET, W. R.; ARNY, D. C.; UPPER, C. D. Relationship between ice nucleation frequency of bacteria and frost injury. Plant Physiology, Washington, v. 70, n. 1, p. 1090-1093, 1982.

MAKI, L. R.; GALYAN, E. L.; CHIWN, M. C.; CALDWELL, D. R. Ice nucleation induced by Pseudomonas syringae. Applied Microbiology, Washington, v. 28, n. 3, p. 456-459, 1974.

MICHIGAMI, Y.; ABE, K.; IWABUCHI, K.; OBATA, H.; ARAI, O. Formation of ice nucleation-active vesicles in Erwinia uredovora at low temperature and transport of InaU molecules into shed vesicles. Bioscience Biotechnology Biochemistry, Tokyo, v. 59, n. 10, p. 19961998, 1995.

MOROHOSHI, T.; NAKAMURA, Y.; YAMAZAKI, G.; SHIDA, A.; KATO, N.; IKEDA, T. The plant pathogen Pantoea ananatis produces N-Acylhomoserine Lactone and causes center rot disease of onion by Quorum Sensing. Journal of Bacteriology, Washington, v. 189, n. 22, p. 8333-8338, 2007.
NEJAD, P.; GRANHALL, U.; RAMSTEDT, M. Factors influencing pathogenic ice-nucleation active (INA) bacteria isolated from Salix plants, soil and litter. Journal of Agricultural Technology, Tehran, v. 1, n. 2, p. 207-222, 2005.

PACCOLA-MEIRELLES, L. D.; FERREIRA, A. S.; MEIRELLES, W. F.; MARRIEL, I. E.; CASELA, C. R. Detection of a bacterium associated with a leaf spot disease of maize in Brazil. Journal of Phytopathology, Berlin, v. 149, n. 1, p. 275-279, 2001.

PHELPS, P.; GIDDINGS, T. H.; PROCHODA, M.; FALL, R. Release of cell-free ice nuclei by Erwinia herbicola. Journal of Bacteriology, Washington, v. 167, n. 2, p. 496-502, 1986.

POMINI, A. M.; PACCOLA-MEIRELLES, L. D.; MARSAIOLI, A. J. Acyl-homoserine lactones produced by Pantoea sp. isolated from the "maize white spot" foliar disease. Journal of Agricultural and Food Chemistry, Washington, v. 55, n. 4, p. 1200-2004, 2007.

ROMEIRO, R. S. Métodos em bacteriologia de plantas. Viçosa: Editora UFV, 2001. 297 p.

RUMJANEK, N. G.; FONSECA, M. C. C.; XAVIER, G. R. Quorum sensing em sistemas agrícolas. Revista Biotecnologia Ciência Desenvolvimento, Brasília, v. 33, n. 33, p. 35-50, 2004.

SAKAI, A; LARCHER, W. Frost survival of plants: responses and adaptation to freezing stress. Berlin: Springer-Verlag, 1987. $321 \mathrm{p}$.

WYSMIERSKI, P. T.; ESCANFERLA, M. E.; PACCOLA-MEIRELLES, L. D. Atividade de nucleação de gelo e produção de exoenzimas em Pantoea ananatis, agente causal da pinta branca do milho Fitopatologia Brasileira, Brasília, v. 30, n. 1, p. 57, 2005. 